\title{
Molybdenum (VI) Binded to Humic and Nitrohumic Acid Models in Aqueous Solutions. Phthalic, 3- and 4-Nitrophthalic Acids, Catechol and 4-Nitrocathecol, Part 1
}

\author{
Ana Lucia R. Mercê $\hat{*}^{*}$, Cristiane Greboge, Giovani Mendes and Antonio S. Mangrich \\ Departamento de Química, Centro Politécnico, Universidade Federal do Paraná, CP 19081, \\ 81531-990 Curitiba - PR, Brazil
}

\begin{abstract}
Inúmeros modelos matemáticos já foram testados na literatura para o estudo de como os ácidos húmicos (AH) se complexam a íons metálicos. Os AH são compostos de produtos naturais degradados contendo C, N, P e S, contendo grupos hidroxila e carboxilatos aromáticos em sua estrutura principal. A presença de íons metálicos ligados a esses sítios de complexação promove a fertilidade do solo, ao mesmo tempo que permite a retenção desses íons para serem liberados lentamente quando da mineralização dos solos. As substâncias nitrohúmicas ( $\mathrm{SNH}$ ) são artefatos de laboratório contendo maior quantidade de $\mathrm{N}$ que os $\mathrm{AH}$, contendo também grupamentos - $\mathrm{NO}_{2}$, que são elétron-atraentes. No entanto esses artefatos ainda possuem a estrutura principal dos $\mathrm{AH}$, contendo os grupamentos salicílicos, catecolatos e ftalatos, todos prontos a reagirem com íons metálicos dependendo das condições do ambiente. Esse trabalho se propôs a estudar a capacidade de complexação de alguns modelos do $\mathrm{AH}$ possuindo diferentes sítios básicos de Lewis na presença do íon metálico Mo(VI), em solução aquosa, conforme a variação de $\mathrm{pH}$ usando algumas técnicas analíticas. As constantes de formação dos complexos do ácido ftálico, 3- e 4- nitroftálico, catecol e 4-nitrocatecol e Mo(VI) bem como a especiação desses complexos de acordo com a variação de $\mathrm{pH}$ foram determinadas. Titulações potenciométricas e ciclo-voltamétricas foram utilizadas para calcular as constantes de formação e para monitorar o aparecimento e a decomposição das espécies complexadas.
\end{abstract}

Many mathematical models have been tested in the literature in the search of how humic acids (HA) from many natural sources complex to metal ions. HA are composed of natural degradation sources of $\mathrm{C}, \mathrm{N}, \mathrm{P}$ and $\mathrm{S}$, bearing hydroxyl and carboxyl aromatic units in their inner structure. The presence of metal ions binded to these basic sites promotes fertility to the soil as well as can hold metal ions to be slowly released as the mineralization of the soil occurs. Nitrohumic substances are a laboratory artifact with higher $\mathrm{N}$ content then humic acids with an electron withdrawing group - $\mathrm{NO}_{2}$. However they still bear the main HA constituent chemical groups such as salycilate, catecholate and phthalate derivatives, all prone to bind to metal ions depending on the chemical conditions of the environment. This work intended to study the complexing behaviour of some HA models having very different Lewis basic binding sites in the presence of molybdenum (VI) ions, in aqueous systems, with varying $\mathrm{pH}$ values using some analytical tools. The formation constants of phthalic acid, 3- and 4-nitrophthalic acids, catechol and 4-nitrocatechol with $\mathrm{Mo}(\mathrm{VI})$ as well as the speciation of the complex species according to varying $\mathrm{pH}$ values were determined. Potentiometric and cyclic voltammetric titrations were employed to calculate the formation constants and to monitor the formation and decomposition of some complexed species. The results showed that although there is complexation between phthalic derived acids and molybdenum, the speciation favours it only until $\mathrm{pH} 6.0$ at the best. On the other hand, salicylic and catechol derived models showed existence of complexation until basic $\mathrm{pH}$ values, allowing a compromising complexation $\mathrm{pH}$ range when humic and nitrohumic substances are involved.

Keywords: humic acid models, molybdenum (VI) complexes, potentiometric titrations, cyclic voltammetry, stability constants

\section{Introduction}

Humic substances, organic material existing in soil and waters arising from the decay of plants and animals play

* e-mail: anamerce@ufpr.br many roles in soils and waters. Among them, they have long been considered as a natural source of C, N, P and S and also, due to their ability to form stable complexes with many metal ions, can be considered as a natural fertilizer. $^{1-2}$ 
Humic substances (HS) and soil organic matter are essential basis for life on earth, and the study of their structures is the aim of a fast growing, interdisciplinary, scientific community, in particular in the environmental sciences. Soil humic acids constitute a very important fraction of soil humus due to their favorable physical, chemical and biological effects on soils. Humic acids appear to be complex polymers of phenolic and other aromatic units having carboxylic and hydroxylic substituents linked to peptide and other $\mathrm{N}$ containing compounds, carbohydrates in small amounts, and different aliphatic compounds. ${ }^{3-10}$ The Humic Acids (HA) are a class of those humic substances, promoting larger or smaller fertility to the soil and water. The structures of HA are partially elucidated in the literature but it is greatly dependent on the starting material and on the climate and other factors of where they are generated..$^{11-13}$

The equilibria of molybdenum (VI) in aqueous solutions are complex, and various polynuclear species in addition to the monomeric species $\mathrm{MoO}_{4}^{2-}, \mathrm{HMoO}_{4}^{-}$, and $\mathrm{H}_{2} \mathrm{MoO}_{4}$ may exist in acidified molybdate solutions. The availability of molybdenum from the sea is relatively high, but its distribution on land is extremely patchy. There are areas where soils generate an agricultural problem due to a deficiency of molybdenum and other areas where the molybdenum is in excess. Perhaps the greatest problem arises from the excess molybdenum in soils since it causes copper deficiency in animals grazing in such lands. ${ }^{14}$

The chemistry of the molybdenum in the soil plays an important role in the reactions where the nitrogenase enzyme is involved. Thus, each molybdenum atom acts as a separate catalytic center, being a significant number of enzymes redox essential for the microorganisms, plant and animal life. Nitrogenase catalyzed substrate reduction reactions require the transient association of the two nitrogenase component proteins, the iron $(\mathrm{Fe})$ protein and the molybdenum iron (MoFe) protein, with the transfer of one electron between the proteins being coupled to the hydrolysis of MgATP. ${ }^{15,16}$

Previous studies in the literature ${ }^{17-21}$ have shown how complex an equilibria involving molybdenum can be. In very acidic solutions the equilibria contain mainly the species of $\mathrm{Mo}(\mathrm{VI})$ protonated $\left(\mathrm{Mo}(\mathrm{OH})_{6}+\mathrm{H}^{+} \leftrightarrows\right.$ $\left.\mathrm{Mo}(\mathrm{OH})_{5} \mathrm{H}_{2} \mathrm{O}^{+}\right)$besides the dimeric species that may occur in significant concentrations, as $\mathrm{Mo}_{2} \mathrm{O}(\mathrm{OH})_{9}\left(\mathrm{H}_{2} \mathrm{O}\right)^{+}$, $\mathrm{Mo}_{2} \mathrm{O}(\mathrm{OH})_{8}\left(\mathrm{H}_{2} \mathrm{O}\right)_{2}{ }^{2+}$ and $\mathrm{Mo}_{2} \mathrm{O}(\mathrm{OH})_{7}\left(\mathrm{H}_{2} \mathrm{O}\right)_{3}{ }^{3+}$ and their equilibria involved in acidic media in the range of 0.4-3.0 mol L-1. In $\mathrm{pH}$ range of 5.5 to 6.2 , the equilibrium studies in aqueous solution of plain molybdate showed a strong affinity of molybdate for hydrogen ions, and the results indicated a stoichiometry corresponding to the formation of para $\mathrm{Mo}_{7} \mathrm{O}_{24}{ }^{6-}$ molybdate anions. There are also formation of polyanions, and the molybdate anion $\left(\mathrm{MoO}_{4}^{2-}\right)$ when in an acidified and diluted solution yields $\mathrm{HMoO}_{4}^{-}$and $\mathrm{H}_{2} \mathrm{MoO}_{4}$, the latter being the octahedral ion $\mathrm{MoO}_{4}^{2-}$ at the stage of second protonation. Species having the stoichiometry such as ligand to metal 1:1, 2:1 and 1:2 are reported when the metal ion is in a solution in the presence of carboxylic derived ligands, although it seems that different experimental conditions and problems with unequivocal interpretation of data arose some contradictory reports.

In the characterization of HS, during the degradation steps ${ }^{10}$ any destructive method to unravel the structure of HS is not possible to determine where specifically or how the cations are bound to the basic sites in the inner structure of HS. The interpretation of the titration curves of humic acids is complicated by the presence of carboxylic, phenolic and amine groups a mixture of acidic species with different acid strengths. In this case, the study of likely models is important to shed some light on the complexation behaviour of those binding sites, generally present in HS. In this respect potentiometric titration has an important role in establishing and quantifying the affinity of metal ions towards binding sites of HS played by some adequate molecular models. Also the complexation of metals by heterogeneous ligands is dependent on metal loading (the rate of bound metal to the binding site concentration).

In order to overcome some of the difficulties in studying metal ions binding to such complex and heterogeneous material such as HS and the drawbacks of all proposed mathematical models so far ${ }^{10,22-31}$ this present study showed the complexation ability of some phthalic derivatives and compared to some catechol derivatives complexation results towards molybdenum using a microcomputer program applied to potentiometric titration data. The stability constants obtained and reported in this work are an average mean of the equilibrium constants for all basic sites present in humic substances existing in the literature so $\operatorname{far}^{32-34}$ and were fully employed in the calculations of the models used to fulfill the metal loading conditions. The speciation according to $\mathrm{pH}$ values were also obtained.

\section{Experimental}

All solutions were made with distilled and deionised $\mathrm{CO}_{2}$ - free water. The reagents were used as received.

\section{Cyclic voltammetric studies}

The electrochemical cell employed supported a 10.0 $\mathrm{mL}$ total volume of solution. The ionic strength was 
maintained at $0.10 \mathrm{~mol} \mathrm{~L}^{-1}$ with $\mathrm{KCl}$ (Merck, Germany). A three electrode system was utilized, being vitrous carbon the working electrode, saturated $\mathrm{Ag} / \mathrm{AgCl}$ the reference electrode, and platinum wire the auxiliary electrode.

The cyclic voltammograms were obtained in a potentiostat/galvanostat (model 273A - EG \& Princeton Applied Research, USA) instrument as a function of each $\mathrm{pH}$, measured using a glass electrode (Analyser Electrode) and a pHmeter (model 320 - Corning,USA), $\mathrm{KOH}$ and $\mathrm{HCl}$ (Merck, Brazil) aqueous solutions 0.1 and $1.0 \mathrm{~mol} \mathrm{~L}^{-1}$ being used to reach the desired $\mathrm{pH}$ values in a de-aired (ultra pure argon) systems at $\mathrm{pH}$ range from 2.5 to 10.0. The experimental conditions of the cyclic voltammetry were the following: range of swept potential: from 0.4 or -0.2 to $1.2 \mathrm{~V}$, the scan rate was $50.00 \mathrm{mV} / \mathrm{s}$ and the initial potential applied was 0.4 or $-0.2 \mathrm{~V}$, at room controlled temperature of $25^{\circ} \mathrm{C}$.

The final concentration of the solutions of molybdenum (VI) (hereafter referred as $\mathrm{MoO}_{2}$ or simply $\mathrm{M}$ ) and the ligands (hereafter referred as $\mathrm{L}$ ) in the cell was $1.0 \times 10^{-2} \mathrm{~mol} \mathrm{~L}^{-1}$ where the ligand to metal ratio was 1:1. Further dilutions were properly made to obtain the metal to ligand ratios of $1: 2$ and 1:3 solutions.

\section{Potentiometric measurements}

To 0.01 millimole of an aqueous solution of ammonium molybdate $\left(\mathrm{NH}_{4} \mathrm{Mo}_{7} \mathrm{O}_{24} \cdot 4 \mathrm{H}_{2} \mathrm{O}\right.$, Carlo Erba, Italy), proper quantities of millimole of solutions of phthalic acid (APA, Sigma, USA), 3-nitrophthalic (3-NPA, Sigma, USA), 4-nitrophthalic acids (4-NPA, Sigma, USA) and 4-nitrocatechol (4-NC, Sigma, USA) to make metal to ligand ratios of $1: 1,1: 2$ and $1: 3$ were added to a thermostated reaction cell maintained at $25.0 \pm 0.1^{\circ} \mathrm{C}$ and ionic strength adjusted to $0.100 \mathrm{~mol} \mathrm{~L}^{-1}(\mathrm{KCl}$, Merck, Germany), final volume $40.00 \mathrm{~mL}$ under inert atmosphere $\left(\mathrm{N}_{2}\right.$ - White Martins, Brazil). The starting APA and NPA solutions were made in 5\%v/v ethanol (Merck, Brazil). The reaction solutions were titrated with standardized $\mathrm{KOH}$ $0.1 \mathrm{~mol} \mathrm{~L}^{-1}$ solutions with the aid of a manual piston burette (Metrohm, Switzerland) and the $\mathrm{pH}$ values read in a $\mathrm{pH}$ meter (Micronal, model B375, Brazil) up to the third significant figure. The $\mathrm{pH}$ meter and a glass and a calomel reference electrodes were previously standardized with $\mathrm{KOH}$ and $\mathrm{HCl}$ (Merck, Brazil) following the literature. ${ }^{35}$ All mathematical algorithms of the microcomputer programs employed, Best7, for the calculations of the protonation and formation constants and SPE for the plotting of the distribution species diagrams, are described elsewhere. ${ }^{35-37}$ All described complexation sites in humic acids with varying degree of complexation were used in all simulation calculations. ${ }^{8-9,33}$

\section{Results and Discussion}

All mathematical equations used for the microcomputer calculations can be summarized below. The complexation reaction of a given metal ion with humic acid can be considered as a metal ion charge neutralization process. In this reaction the metal ion occupies the number of proton exchange sites equal to its charge $(\mathrm{z}+)$, as in equation 1 .

$\mathrm{M}+\mathrm{HA}(\mathrm{z}) \leftrightarrows \mathrm{MHA}(\mathrm{z})$

Based in this equation, the complexation constant can be stated as in equation 2 .

$\beta=[\operatorname{MHA}(\mathrm{z})] /[\mathrm{M}]_{\mathrm{f}} \mathrm{x}[\mathrm{HA}(\mathrm{z})]_{\mathrm{f}}$

where $[\mathrm{MHA}(\mathrm{z})]$ is the concentration of metal ion humate complex, $[\mathrm{M}]_{\mathrm{f}}$ is the free metal ion concentration and $[\mathrm{HA}(\mathrm{z})]_{\mathrm{f}}$ the free humic acid concentration. Those equations were the mathematical model basis of the calculations of the stability constants.

The metal loading conditions were varied in the calculations using both the stability constants for the binding sites in the matrix of the model employed as well as the various possible degrees of occupation of these sites, till a minimization of the error of the potentiometric titrated system occurred.

Figures 1 to 4 showed the potentiometric $\mathrm{pH}$ profiles of 3-NPA, APA, 4-NPA and 4-NC plus molybdenum (VI), respectively. All four studied systems showed crescent uptake of protons at the beginning of the titrations when going from metal to ligand ratios of $1: 3$ to $1: 1$, in the $\mathrm{pH}$ values around 2.5 to 4.0 . This pattern has been shown in all studied systems with $\mathrm{Mo}^{6+}$ because molybdate (an anion) was the starting reagent. The aforementioned capability of uptaking protons equilibria can be summarised in equations 3 and 4.

$$
\begin{aligned}
\mathrm{MoO}_{4}^{2-}+\mathrm{H}^{+} \leftrightarrows & {\left[\mathrm{MoO}_{3}(\mathrm{OH})\right]^{-} } \\
{\left[\mathrm{MoO}_{3}(\mathrm{OH})\right]^{-}+\mathrm{H}^{+}+2 \mathrm{H}_{2} \mathrm{O} \leftrightarrows } & \mathrm{Mo}(\mathrm{OH})_{6} \text { or } \\
& \mathrm{MoO}_{2}(\mathrm{OH})_{2}\left(\mathrm{H}_{2} \mathrm{O}\right)_{2}
\end{aligned}
$$

Following this stage of uptaking of protons, when $\mathrm{Mo}^{6+}$ is present (after $\mathrm{pH} 4.0$ ), the complexation began and the calculated complexed species formed in the systems above $10 \%$ of the total species added are shown in Table 1, as well as catechol and $\mathrm{Mo}^{6+}$ taken from the literature. ${ }^{32}$

The behaviour of molybdate in water as the $\mathrm{pH}$ was raised had added some new considerations in the 


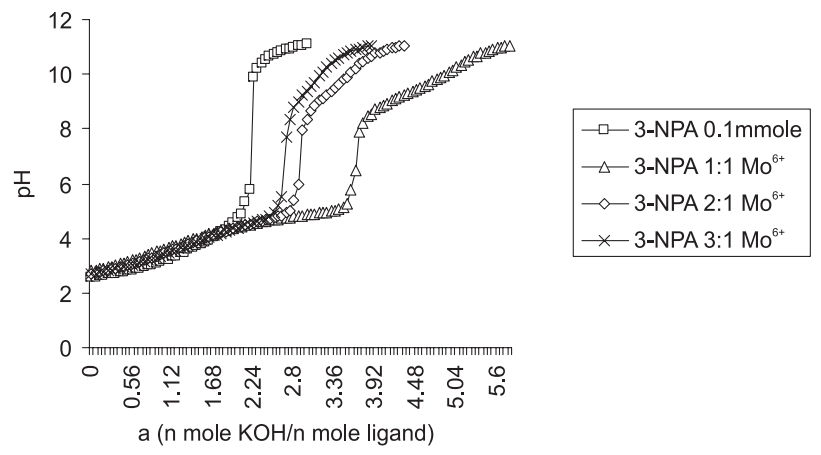

Figure 1. Potentiometric $\mathrm{pH}$ profile of $\mathrm{MoO}_{2}$ and 3-NPA (L)in several metal to ligand ratios. $\mathrm{T}=25.0{ }^{\circ} \mathrm{C}, \mathrm{I}=0.100 \mathrm{~mol} \mathrm{~L}^{-1}$.

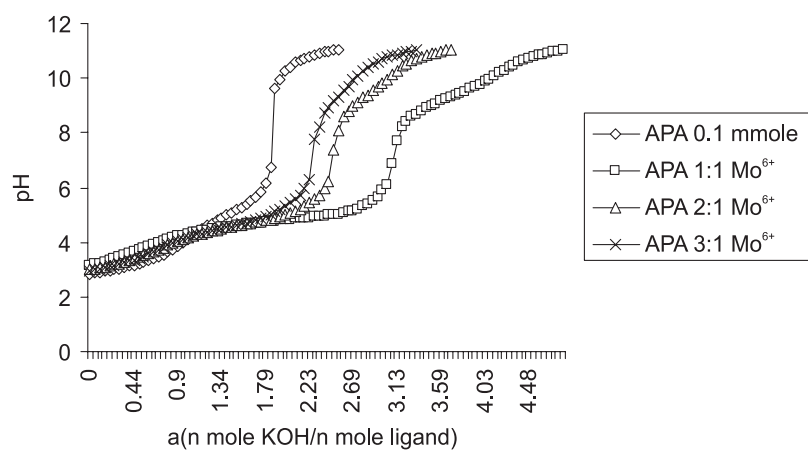

Figure 2. Potentiometric pH profile of $\mathrm{MoO}_{2}(\mathrm{M})$ and $\mathrm{APA}(\mathrm{L})$ in several metal to ligand ratios. $\left(\mathrm{T}=25.0{ }^{\circ} \mathrm{C}, \mathrm{I}^{2}=0.100 \mathrm{~mol} \mathrm{~L}^{-1}\right)$.

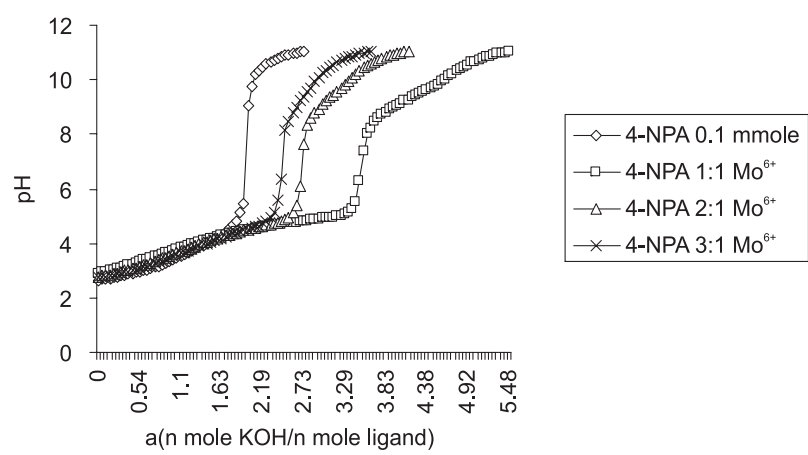

Figure 3. Potentiometric $\mathrm{pH}$ profile of $\mathrm{MoO}_{2}(\mathrm{M})$ and 4-NPA (L) in several metal to ligand ratios. $\left(\mathrm{T}=25.0{ }^{\circ} \mathrm{C}, \mathrm{I}=0.100 \mathrm{~mol} \mathrm{~L}^{-1}\right)$.

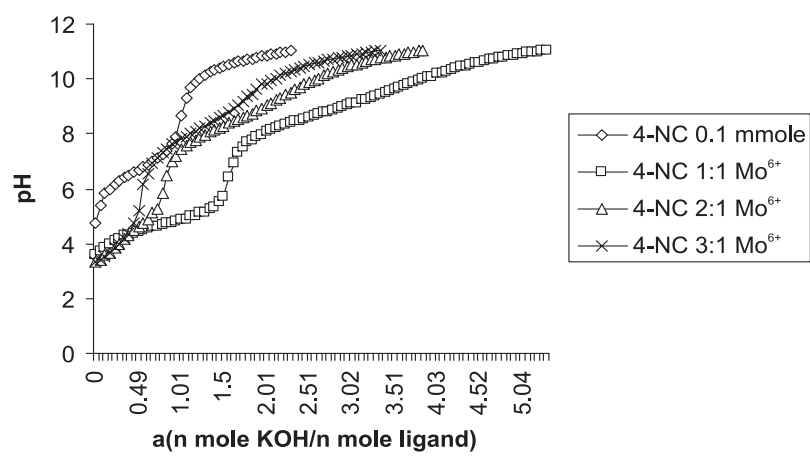

Figure 4. Potentiometric $\mathrm{pH}$ profile of $\mathrm{MoO}_{2}(\mathrm{M})$ and 4-NC (L) in several metal to ligand ratios. $\left(\mathrm{T}=25.0{ }^{\circ} \mathrm{C}, \mathrm{I}=0.100 \mathrm{~mol} \mathrm{~L}^{-1}\right)$.
Table 1. Logarithms of the formation constants for the ligands (L) and molybdenum (VI) $\left(\mathrm{MoO}_{2}=\mathrm{M}\right) . \mathrm{T}=25.0^{\circ} \mathrm{C}$ and $\mathrm{I}=0.100 \mathrm{~mol}$ $\mathrm{L}^{-1}(\mathrm{KCl})$

\begin{tabular}{ll}
\hline $\mathrm{L}$ & $\mathrm{MoO}_{2}=\mathrm{M}$ \\
\hline $4-\mathrm{NPA}$ & $3.8 \pm 0.5$ \\
{$[\mathrm{ML}] /[\mathrm{M}] \times[\mathrm{L}]$} & $7.4 \pm 0.5$ \\
{$\left[\mathrm{ML}_{2}\right] /[\mathrm{M}] \times[\mathrm{L}]^{2}$} & \\
$3-\mathrm{NPA}$ & $4.0 \pm 0.5$ \\
{$[\mathrm{ML}] /[\mathrm{M}] \times[\mathrm{L}]$} & $7.7 \pm 0.5$ \\
{$\left[\mathrm{ML}_{2}\right] /[\mathrm{M}] \times[\mathrm{L}]^{2}$} & \\
$\mathrm{APA}$ & $5.4 \pm 0.5$ \\
{$[\mathrm{ML}] /[\mathrm{M}] \times[\mathrm{L}]$} & $9.5 \pm 0.5$ \\
{$\left[\mathrm{ML} / /[\mathrm{M}] \times[\mathrm{L}]^{2}\right.$} & \\
$4-\mathrm{NC}$ & $11.9 \pm 0.8$ \\
{$[\mathrm{ML}] /[\mathrm{M}] \times[\mathrm{L}]$} & $5.0 \pm 0.8$ \\
{$[\mathrm{MHL}] /[\mathrm{ML}] \times[\mathrm{H}]$} & $22.8 \pm 0.8$ \\
{$\left[\mathrm{ML}_{2}\right] /[\mathrm{M}] \times[\mathrm{L}]^{2}$} & \\
$\mathrm{CATECHOL}^{2}$ & $5.1 \pm 0.2^{32}$ \\
\hline $\left.\mathrm{ML}_{2}\right] /\left[\mathrm{MO}{ }_{2}\right] \times\left[\mathrm{H}_{2} \mathrm{~L}\right]^{2}$ & \\
\hline
\end{tabular}

${ }^{32}$ Refer to reference 32 .

calculations made. So many were the possibilities that the calculations had to be made in two steps. First considering the region of the potentiometric titration profiles until the uptaking of protons were finished, and second, after this step, where all metal ions were in the form of $\mathrm{Mo}^{6+}$. The first part of calculations have turned out into no possible detected complexed species under the experimental conditions used.

The non nitro HS phthalic model is the strongest Lewis base towards $\mathrm{Mo}^{6+}$, as expected when compared to the nitrophthalic models. The latter ligands presented very similar formation constants either for $\mathrm{ML}$ and $\mathrm{ML}_{2}$ indicating that the different stereochemical position of the nitro substituent didn't affect the strenght of the basic sites towards the metal ion $\mathrm{Mo}^{6+}$.

When two hydroxyl substituents in the aromatic ring (catechol derivatives) are at stake the behaviour of the basic sites are the expected, having the nitro substituent an electron withdrawing effect in the aromatic ring, thus lowering the Lewis basicity, in spite of that exhibiting higher formation constants than when two carboxyl groups are the substituents (phthalic derivatives). It was not possible to perform experimental studies with catechol and $\mathrm{Mo}^{6+}$ due to early formation of insoluble products in the equilibria tried.

The species distribution diagrams showed the formation of species $\mathrm{ML}$ and $\mathrm{ML}_{2}$ for the nitro compounds starting from acidic $\mathrm{pH}$ values (2.0) and being decomposed near $\mathrm{pH}$ 5.5. APA showed the same starting complex formation $\mathrm{pH}$ but the species were decomposed near $\mathrm{pH}$ 6.5. Only 4-NC presented a species distribution diagram starting to form the complexed species MHL around $\mathrm{pH}=2.0$ but $\mathrm{ML}_{2}$ lasted till $\mathrm{pH} 11.0$, reaching its maximum at $\mathrm{pH} 8.5$. 
The suitability of the binding sites present in the HS likely models to complex and hold $\mathrm{Mo}^{6+}$ in the adequate $\mathrm{pH}$ values for the fertility of soils was only observed for 4-NC, as either the complexes of APA and NPA are decomposed at $\mathrm{pH}$ values above 6.5 at the best. The phthalic binding sites, carboxylate groups are less suitable than the hydroxyls groups of the catecholate binding sites.

The cyclic voltammetric technique has added some information despite the irreversibility of the obtained voltammograms. A comparison among the variations in the shape of the cyclic voltammograms of the complexed and not complexed systems can be made taking a look at Figures 5 to 14. Figures 5, 6 and 7 presented the cyclic voltammograms of 3-NPA, molybdenum and APA alone taken in the $\mathrm{pH}$ values near the corresponding protonation values for each studied ligand. 4-NC aqueous solutions are not electrochemically active. In the cyclic voltammogram of molybdenum (Figure 6) which covered a wide range of $\mathrm{pH}$ values it is possible to see that many different species arise in the aqueous equilibria of molybdate. It was not possible however to assign every

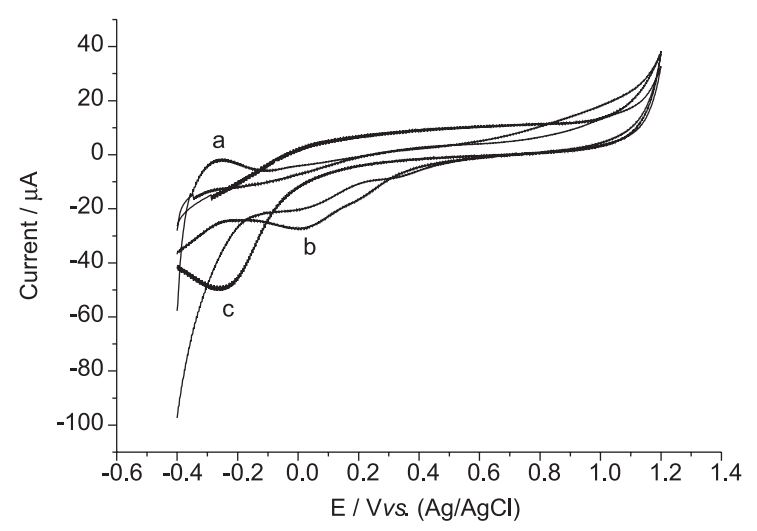

Figure 5. Cyclic voltammograms $(50.00 \mathrm{mV} / \mathrm{s})$ of $3-\mathrm{NPA} 1.0 \times 10^{-2}$ $\mathrm{mol} \mathrm{L}^{-1}$, a) $\mathrm{pH} 2.23$; b) $\mathrm{pH} 4.00$ and c) $\mathrm{pH} 8.08$. From E/V 1.2 to $0.4 \mathrm{~V}$. $\left(\mathrm{T}=25^{\circ} \mathrm{C}, \mathrm{I}=0.10 \mathrm{~mol} \mathrm{~L}^{-1}, \mathrm{KCl}\right)$.

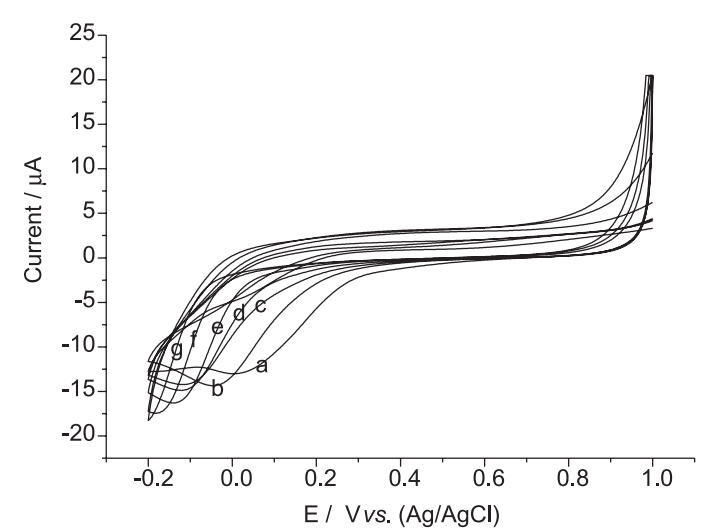

Figure 6. Cyclic voltammograms $(50.00 \mathrm{mV} / \mathrm{s})$ of a) $\mathrm{M}$ alone, $\mathrm{pH}$ 2.64; b) $\mathrm{pH} 4.93$; c) $\mathrm{pH} 5.87$; d) $\mathrm{pH} 7.04$; e) $\mathrm{pH} 8.13$; f) $\mathrm{pH} 9.08$ and g) $\mathrm{pH} 9.80$. From E/V 1.0 to $-0.2 \mathrm{~V}, 1.0 \times 10^{-2} \mathrm{~mol} \mathrm{~L}^{-1}$. $\left(\mathrm{T}=25{ }^{\circ} \mathrm{C}\right.$, $\left.\mathrm{I}=0.10 \mathrm{~mol} \mathrm{~L}^{-1}, \mathrm{KCl}\right)$. species to every obtained cyclic voltamogramm. Some of them were stated previously, in equations 3 and 4.

Figures 8 and 9 refer to 3-NPA and M, 10 and 11, 4-NPA and M, 12 and 13, APA and M and 14, 4-NC and M, respectively, in ligand to metal ratios of 1:1 and 2:1, except for 4-NC, which was only shown in the 1:1 ratio, at several $\mathrm{pH}$ values, corresponding to the main species formation in the highest percentage possible with data taken from the obtained species distribution diagrams. The ligand to metal ratio of 3:1 presented a very similar behaviour from the $2: 1$ ratio for all studied ligands so the cyclic voltammograms were not shown. The same happened to 4-NC in the ligand to metal ratios of 1:1 and 2:1.

From those cyclic voltammograms figures it was possible to follow the formation and the decomposition of the species found using the potentiometric titrations data by comparing the potential variations as well as the shape in the obtained curves in the corresponding $\mathrm{pH}$ values. Some of the obtained cyclic voltammograms were not well defined due to mixed complexed and/or hydrolysis species in the equilibria measured.

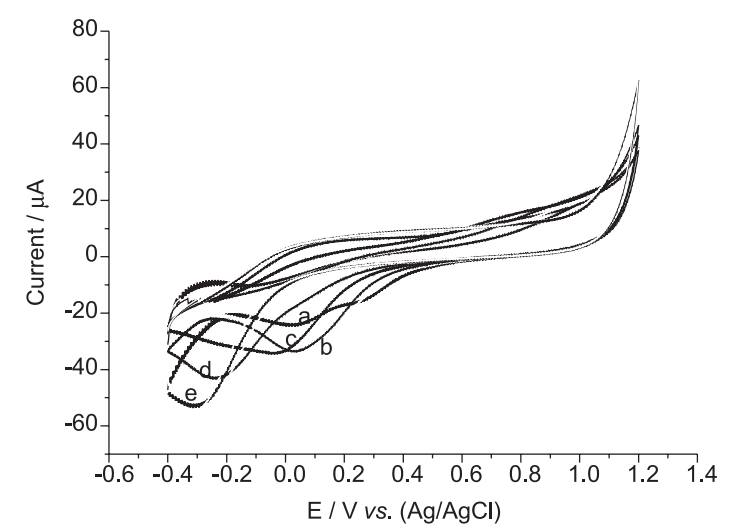

Figure 7. Cyclic voltammograms $(50.00 \mathrm{mV} / \mathrm{s})$ of APA alone, $1.0 \mathrm{x}$ $10^{-2} \mathrm{~mol} \mathrm{~L}^{-1}$ a) $\mathrm{pH} 3.03$; b) $\mathrm{pH} 4.60$; c) $\mathrm{pH} 5.68$; d) $\mathrm{pH} 6.36$ and e) $\mathrm{pH}$ 8.70. From E/V 1.2 to $-0.4 \mathrm{~V}$. $\left(\mathrm{T}=25^{\circ} \mathrm{C}, \mathrm{I}=0.10 \mathrm{~mol} \mathrm{~L}^{-1}, \mathrm{KCl}\right)$.

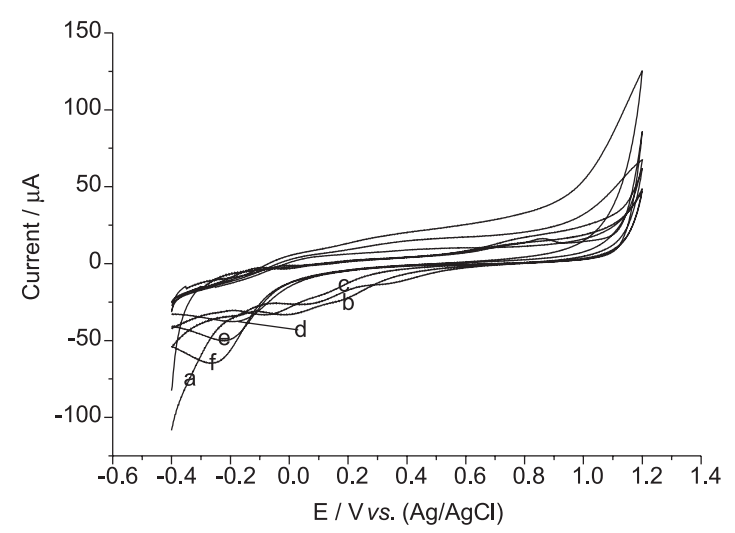

Figure 8. Cyclic voltammograms $(50.00 \mathrm{mV} / \mathrm{s})$ of 3 -NPA and $\mathrm{M}$ (ligand to metal ratio of $1: 1$ ) at a) $\mathrm{pH} 2.03$; b) $\mathrm{pH} 3.96$; c) $\mathrm{pH} 5.01$; d) $\mathrm{pH} 7.10$; e) $\mathrm{pH} 8.88$ and f) $\mathrm{pH} 9.84$. From 1.2 to $-0.4 \mathrm{~V}$. ( $(\mathrm{T}=$ $25^{\circ} \mathrm{C}, \mathrm{I}=0.10 \mathrm{~mol} \mathrm{~L}^{-1} \mathrm{KCl}$ ). 


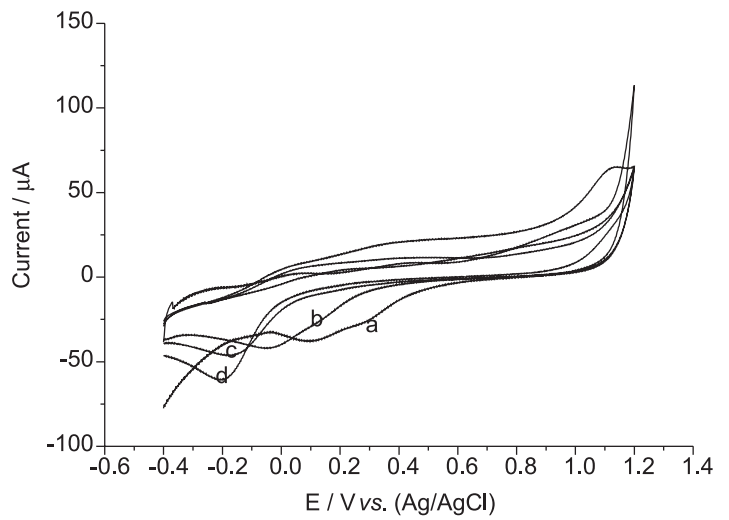

Figure 9. Cyclic voltammograms $(50.00 \mathrm{mV} / \mathrm{s})$ of 3-NPA and $\mathrm{M}$ (ligand to metal ratio 2:1) at a) $\mathrm{pH} 3.77$ and b) $\mathrm{pH} 5.01$ and c) $\mathrm{pH}$ 7.00 and d) $\mathrm{pH}$ 9.42. From 1.2 to $-0.4 \mathrm{~V}$. $\left(\mathrm{T}=25{ }^{\circ} \mathrm{C}, \mathrm{I}=0.10 \mathrm{~mol} \mathrm{~L}^{-1}\right.$, $\mathrm{KCl})$.

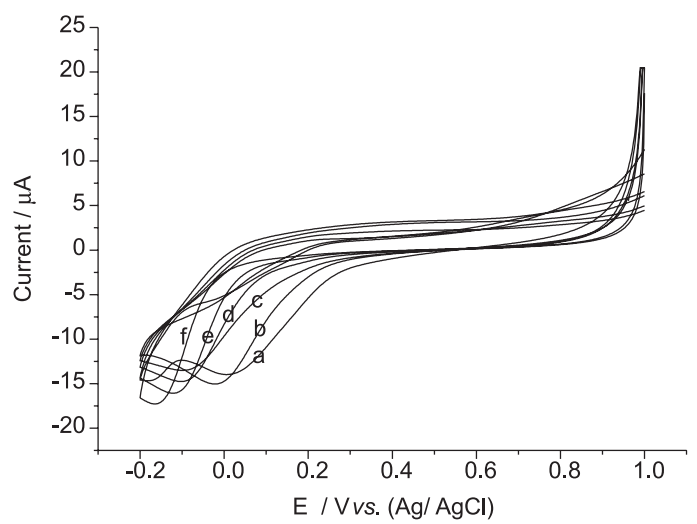

Figure 10. Cyclic voltammograms $(50.00 \mathrm{mV} / \mathrm{s})$ of $4-\mathrm{NPA}$ and $\mathrm{M}$ (ligand to metal to ratio $1: 1$ ) at a) $\mathrm{pH} 3.46$; b) $\mathrm{pH} 4.96$; c) $\mathrm{pH} 6.39$; d) $\mathrm{pH} 7.27$; e) $\mathrm{pH} 8.42$ and f) $\mathrm{pH} 9.17$. From 1.0 to $-0.2 \mathrm{~V}$. ( $\mathrm{T}=$ $\left.25^{\circ} \mathrm{C}, \mathrm{I}=0.10 \mathrm{~mol} \mathrm{~L}^{-1}, \mathrm{KCl}\right)$.

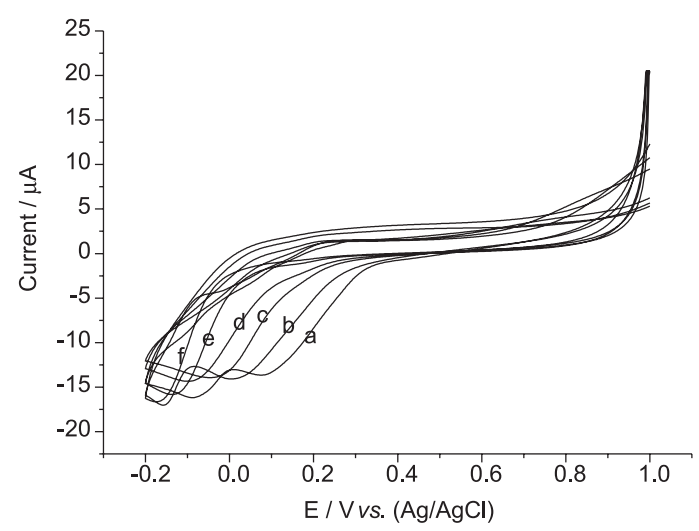

Figure 11. Cyclic voltammograms $(50.00 \mathrm{mV} / \mathrm{s})$ of $4-\mathrm{NPA}$ and $\mathrm{M}$ (ligand to metal ratio $2: 1$ ) at a) $\mathrm{pH} 2.84$; b) $\mathrm{pH} 4.01$; c) $\mathrm{pH} 5.60$; d) $\mathrm{pH} 6.50$; e) $\mathrm{pH} 8.45$ and f) $\mathrm{pH} 9.39$. From 1.0 to $-0.2 \mathrm{~V}$. ( $\mathrm{T}=25^{\circ} \mathrm{C}$, $\left.\mathrm{I}=0.10 \mathrm{~mol} \mathrm{~L}^{-1}, \mathrm{KCl}\right)$.

From equation 5 it's possible to calculate the half wave potential, $\mathrm{E}_{1 / 2}$.

$\mathrm{E}_{1 / 2}=\mathrm{E}^{0}-0.059(\mathrm{~m} / \mathrm{n}) \mathrm{pH}$

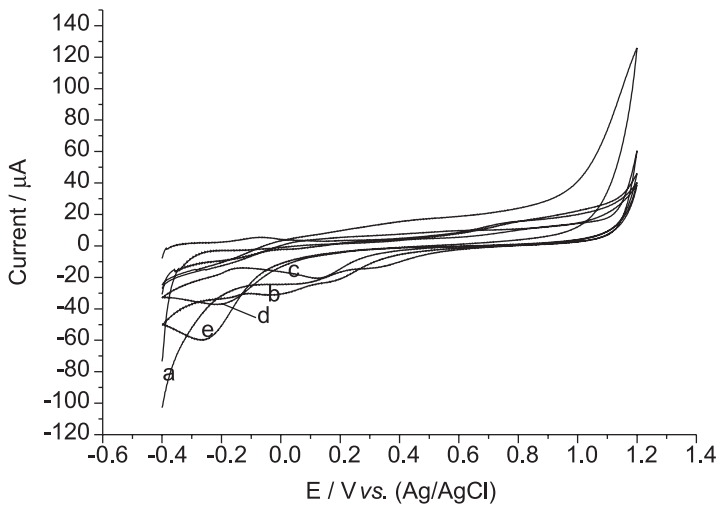

Figure 12. Cyclic voltammograms $(50.00 \mathrm{mV} / \mathrm{s})$ of APA and $\mathrm{M}$ (ligand to metal ratio $1: 1$ ) at a) $\mathrm{pH} 2.03$; b) $\mathrm{pH} 3.89$; c) $\mathrm{pH} 4.68$; d) $\mathrm{pH} 7.01$ and e) $\mathrm{pH} 9.94$. From 1.2 to $-0.4 \mathrm{~V}$. $\left(\mathrm{T}=25^{\circ} \mathrm{C}, \mathrm{I}=0.10 \mathrm{~mol}\right.$ $\left.\mathrm{L}^{-1}, \mathrm{KCl}\right)$.

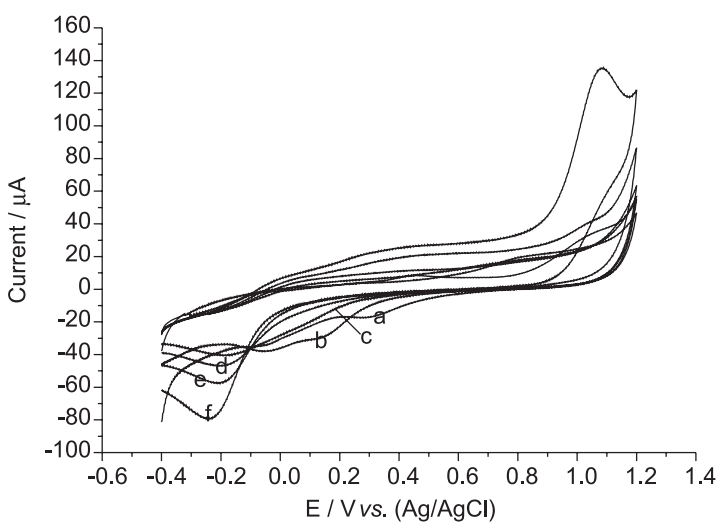

Figure 13. Cyclic voltammograms $(50.00 \mathrm{mV} / \mathrm{s})$ of $\mathrm{APA}$ and $\mathrm{M}$ (ligand to metal ratio $2: 1$ ) at a) $\mathrm{pH} 2.24$; b) $\mathrm{pH} 4.49$; c) $\mathrm{pH} 5.96$; d) $\mathrm{pH} 7.02$; e) $\mathrm{pH} 8.70$ and f) $\mathrm{pH} 9.54$. From 1.2 to $-0.4 \mathrm{~V}$. ( $\left(\mathrm{T}=25^{\circ} \mathrm{C}\right.$, $\left.\mathrm{I}=0.10 \mathrm{~mol} \mathrm{~L}^{-1}, \mathrm{KCl}\right)$.

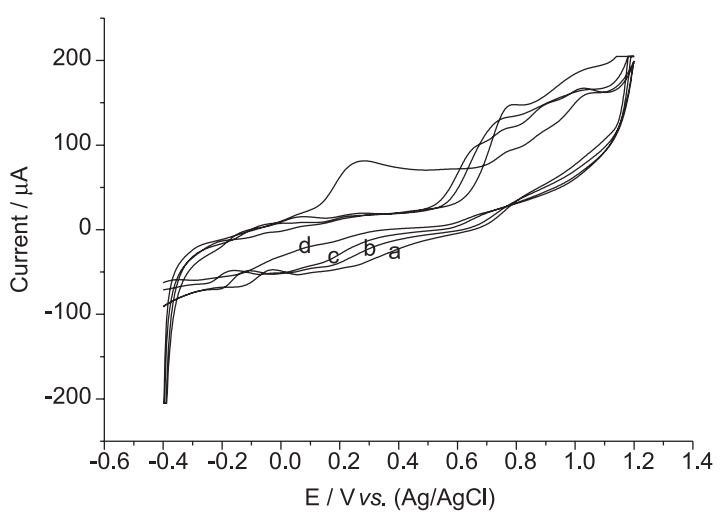

Figure 14. Cyclic voltammograms $(50.00 \mathrm{mV} / \mathrm{s})$ of $4-\mathrm{NC}$ and $\mathrm{M}$

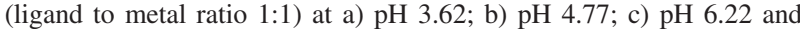
d) $\mathrm{pH} 9.10$. From 1.2 to $-0.4 \mathrm{~V}$. $\left(\mathrm{T}=25^{\circ} \mathrm{C}, \mathrm{I}=0.10 \mathrm{~mol} \mathrm{~L}^{-1}, \mathrm{KCl}\right)$.

where $\mathrm{E}_{1 / 2}$ is the half wave potential, $\mathrm{E}^{0}$ is the standard potential at $298 \mathrm{~K}, \mathrm{~m}$ is the proton number, and $\mathrm{n}$ is the electron number transferred in the redox process. From equation 5 another one can be deduced (equation 6) where 
$\mathrm{m} / \mathrm{n}$ can be calculated from the slope of the curve $\mathrm{E}_{1 / 2}=$ $\mathrm{f}(\mathrm{pH})$.

$\mathrm{m} / \mathrm{n}=\Delta \mathrm{E}_{\mathrm{pa}} /-0.059 \Delta \mathrm{pH}$

The values for $\mathrm{E}_{\mathrm{pa}}$ in the obtained cyclic voltammograms (refer to Figures 5 to 14) are in Tables $2 \mathrm{a}$ and $2 \mathrm{~b}$.

From the data displayed in Tables $2 \mathrm{a}$ and $2 \mathrm{~b}$, it was possible to calculate the number of protons transferred in the reduction process for each transferred electron as for 3-NPA (Figures 8 and 9), in metal to ligand ratios of 1:1 and $1: 2,0.9966$ for $\mathrm{E}_{\mathrm{pa}}=0.00129 \mathrm{~V}$ in $\mathrm{pH} 3.96$ and $\mathrm{E}_{\mathrm{pa}}=$ $0.05715 \mathrm{~V}$ in $\mathrm{pH} 3.01$, and 1.5516 for $\mathrm{E}_{\mathrm{pa}}=0.04473 \mathrm{~V}$ in $\mathrm{pH} 4.10$ and $\mathrm{E}_{\mathrm{pa}}=0.1317 \mathrm{~V}$ in $\mathrm{pH} 3.15$, respectively. The ligand 4-NPA (refer to Figures 10 and 11 for the cyclic voltammograms) showed $\mathrm{m} / \mathrm{n}$ values for metal to ligand ratios of $1: 1$ and $1: 2$ of 0.7377 for $\mathrm{E}_{\mathrm{pa}}=0.1008 \mathrm{~V}$ in $\mathrm{pH}$
6.39 and $\mathrm{E}_{\mathrm{pa}}=-0.0181 \mathrm{~V}$ in $\mathrm{pH} 4.96$, and 1.0714 for $\mathrm{E}_{\mathrm{pa}}=$ $0.00783 \mathrm{~V}$ in $\mathrm{pH} 4.01$ and for $\mathrm{E}_{\mathrm{pa}}=0.08179 \mathrm{~V}$ in $\mathrm{pH} 2.84$, respectively. Although $\mathrm{ML}_{2}$ for 4-NPA was present in the equilibrium in a quantity higher than $10 \%$ of total added metal concentration, the obtained cyclic voltammograms didn't show a value higher than 1 for the number of protons/ electrons transferred in the ligand to metal ratio of $2: 1$ as would be expected for the participation of two ligands for each metal ion complexed species.

For APA in metal to ligand ratios of 1:1 and 1:2, 1.3249 for $\mathrm{E}_{\mathrm{pa}}=0.04473 \mathrm{~V}$ in $\mathrm{pH} 3.00$ and $\mathrm{E}_{\mathrm{pa}}=0.06080 \mathrm{~V}$ in $\mathrm{pH}$ 4.35 , and 2.1053 for $\mathrm{E}_{\mathrm{pa}}=0.07320 \mathrm{~V}$ in $\mathrm{pH} 5.01$ and $\mathrm{E}_{\mathrm{pa}}=$ $0.19125 \mathrm{~V}$ in $\mathrm{pH} 5.96$, respectively. The cyclic voltammograms are in Figures 12 and 13.

For the ligand 4-NC (cyclic voltammograms in Figure 14), the presence of MHL in the system has somehow disturbed the evaluation of $\mathrm{E}_{\mathrm{pa}}$ of the system for the metal to ligand ratio of 1:1. For the metal to ligand ratio of $1: 2$

Table 2a. $\mathrm{E}_{\mathrm{pa}}(\mathrm{V})$ for the cyclic voltammograms obtained at different $\mathrm{pH}$ values (inside parenthesis) for the solutions of the ligands APA and 3-NPA and Molybdenum $\left(\mathrm{MoO}_{2}=\mathrm{M}\right)$ and the ligands in the presence of $\mathrm{M}$ in ligand to metal ratios of 1:1, 2:1 and 3:1

\begin{tabular}{|c|c|c|c|c|c|c|c|c|}
\hline \multirow[b]{2}{*}{$\mathrm{M}$} & \multicolumn{8}{|c|}{$\mathrm{E}_{\mathrm{pa}}$} \\
\hline & $\begin{array}{c}0.0078 \\
(2.64)\end{array}$ & n.d. & $\begin{array}{c}-0.0355 \\
(4.23)\end{array}$ & $\begin{array}{c}-0.0442 \\
(4.93)\end{array}$ & $\begin{array}{c}-0.1181 \\
(5.87)\end{array}$ & $\begin{array}{c}-0.1181 \\
(7.04)\end{array}$ & $\begin{array}{c}-0.1355 \\
(8.13)\end{array}$ & $\begin{array}{c}-0.1834 \\
(9.08)\end{array}$ \\
\hline APA & n.d. & $\begin{array}{c}0.1988 \\
(3.03)\end{array}$ & $\begin{array}{c}0.0323 \\
(4.00)\end{array}$ & $\begin{array}{c}0.01371 \\
(5.14)\end{array}$ & $\begin{array}{c}-0.2346 \\
(6.36)\end{array}$ & $\begin{array}{c}-0.2782 \\
(7.88)\end{array}$ & $\begin{array}{c}-0.3092 \\
(8.70)\end{array}$ & $\begin{array}{c}-0.3340 \\
(9.25)\end{array}$ \\
\hline 3-NPA & n.d. & $\begin{array}{c}0.0012 \\
(3.15)\end{array}$ & $\begin{array}{c}0.00745 \\
(4.00)\end{array}$ & $\begin{array}{c}-0.2222 \\
(5.53)\end{array}$ & $\begin{array}{c}-0.2346 \\
(6.65)\end{array}$ & $\begin{array}{c}-0.2471 \\
(7.50)\end{array}$ & $\begin{array}{c}-0.2658 \\
(8.08)\end{array}$ & $\begin{array}{c}-0.2719 \\
(9.38)\end{array}$ \\
\hline $\begin{array}{c}\text { APA:M } \\
1: 1\end{array}$ & n.d. & $\begin{array}{c}0.04473 \\
(3.00)\end{array}$ & $\begin{array}{c}-0.0608 \\
(4.35)\end{array}$ & $\begin{array}{c}-0.0856 \\
(4.95)\end{array}$ & $\begin{array}{c}-0.1974 \\
(6.18)\end{array}$ & $\begin{array}{c}-0.2098 \\
(7.01)\end{array}$ & $\begin{array}{c}-0.2285 \\
(8.10)\end{array}$ & n.d. \\
\hline $\begin{array}{c}\text { APA:M } \\
2: 1\end{array}$ & $\begin{array}{c}-0.0794 \\
(2.24)\end{array}$ & $\begin{array}{c}-0.0235 \\
(3.01)\end{array}$ & $\begin{array}{c}-0.0545 \\
(4.49)\end{array}$ & $\begin{array}{c}-0.0732 \\
(5.01)\end{array}$ & $\begin{array}{c}-0.1912 \\
(5.96)\end{array}$ & $\begin{array}{c}-0.1974 \\
(7.02)\end{array}$ & $\begin{array}{c}-0.2098 \\
(7.72)\end{array}$ & $\begin{array}{c}-0.2098 \\
(8.70)\end{array}$ \\
\hline $\begin{array}{c}\text { APA:M } \\
3: 1\end{array}$ & $\begin{array}{c}0.00745 \\
(2.31)\end{array}$ & $\begin{array}{c}-0.0981 \\
(3.75)\end{array}$ & $\begin{array}{c}-0.1353 \\
(4.42)\end{array}$ & $\begin{array}{c}-0.1912 \\
(5.15)\end{array}$ & n.d. & n.d. & $\begin{array}{c}-0.1478 \\
(8.45)\end{array}$ & $\begin{array}{c}-0.1912 \\
(9.14)\end{array}$ \\
\hline $\begin{array}{c}\text { 3NPA:M } \\
1: 1\end{array}$ & n.d. & $\begin{array}{c}0.05715 \\
(3.01)\end{array}$ & $\begin{array}{c}0.00129 \\
(3.96)\end{array}$ & $\begin{array}{c}-0.0732 \\
(5.01)\end{array}$ & n.d. & $\begin{array}{c}-0.1849 \\
(7.10)\end{array}$ & $\begin{array}{c}-0.1974 \\
(7.95)\end{array}$ & $\begin{array}{c}-0.2161 \\
(8.88)\end{array}$ \\
\hline $\begin{array}{c}\text { 3NPA:M } \\
2: 1\end{array}$ & $\begin{array}{c}0.17514 \\
(2.32)\end{array}$ & $\begin{array}{c}0.1317 \\
(3.15)\end{array}$ & $\begin{array}{c}0.04473 \\
(4.10)\end{array}$ & $\begin{array}{c}-0.0235 \\
(5.01)\end{array}$ & n.d. & n.d. & n.d. & $\begin{array}{c}-0.1725 \\
(8.84)\end{array}$ \\
\hline $\begin{array}{c}\text { 3NPA:M } \\
3: 1\end{array}$ & $\begin{array}{c}-0.0297 \\
(2.47)\end{array}$ & $\begin{array}{c}-0.0732 \\
(3.20)\end{array}$ & $\begin{array}{c}-0.1415 \\
(4.31)\end{array}$ & $\begin{array}{c}-0.0484 \\
(5.26)\end{array}$ & n.d. & n.d. & $\begin{array}{c}-0.1602 \\
(8.57)\end{array}$ & $\begin{array}{c}-0.2346 \\
(9.48)\end{array}$ \\
\hline
\end{tabular}

( ) actually measured $\mathrm{pH}$ values; n.d. not detected.

Table 2b. $\mathrm{E}_{\mathrm{pa}}(\mathrm{V})$ for the cyclic voltammograms obtained at different $\mathrm{pH}$ values (inside parenthesis) for the solutions of the ligands 4-NPA and 4-NC in the presence of Molybdenum $\left(\mathrm{MoO}_{2}=\mathrm{M}\right)$ in the ligand to metal ratios of 1:1, 2:1 and 3:1 for 4-NPA and 1:1 and 2:1 for 4-NC

\begin{tabular}{|c|c|c|c|c|c|c|c|c|}
\hline \multirow[b]{2}{*}{$\begin{array}{c}\text { 4NPA:M } \\
1: 1\end{array}$} & \multicolumn{8}{|c|}{$\mathrm{E}_{\mathrm{pa}}$} \\
\hline & n.d. & $\begin{array}{c}0.01221 \\
(3.46)\end{array}$ & $\begin{array}{c}-0.0051 \\
(4.44)\end{array}$ & $\begin{array}{c}-0.0181 \\
(4.96)\end{array}$ & $\begin{array}{c}-0.1008 \\
(6.39)\end{array}$ & $\begin{array}{c}-0.0964 \\
(7.27)\end{array}$ & $\begin{array}{c}-0.1138 \\
(8.42)\end{array}$ & n.d. \\
\hline $\begin{array}{c}\text { 4NPA:M } \\
2: 1\end{array}$ & $\begin{array}{c}0.08179 \\
(2.84)\end{array}$ & n.d. & $\begin{array}{c}0.00783 \\
(4.01)\end{array}$ & $\begin{array}{c}-0.0268 \\
(4.97)\end{array}$ & $\begin{array}{c}-0.0964 \\
(6.50)\end{array}$ & $\begin{array}{c}-0.1094 \\
(7.60)\end{array}$ & $\begin{array}{c}-0.1355 \\
(8.45)\end{array}$ & n.d. \\
\hline $\begin{array}{c}\text { 4NPA:M } \\
3: 1\end{array}$ & $\begin{array}{c}0.08179 \\
(2.45)\end{array}$ & $\begin{array}{c}0.01221 \\
(3.52)\end{array}$ & $\begin{array}{c}-0.0078 \\
(4.23)\end{array}$ & $\begin{array}{c}-0.0051 \\
(5.03)\end{array}$ & n.d. & $\begin{array}{c}-0.1094 \\
(7.41)\end{array}$ & $\begin{array}{c}-0.1181 \\
(8.23)\end{array}$ & $\begin{array}{c}-0.1442 \\
(9.05)\end{array}$ \\
\hline $\begin{array}{c}\text { 4NC:M } \\
1: 1\end{array}$ & n.d. & $\begin{array}{c}0.0621 \\
(3.62)\end{array}$ & n.d. & n.d & n.d & n.d. & n.d. & n.d. \\
\hline $\begin{array}{c}\text { 4NC:M } \\
2: 1\end{array}$ & $\begin{array}{c}0.15648 \\
(1.66)\end{array}$ & n.d. & $\begin{array}{c}0.0493 \\
(4.16)\end{array}$ & $\begin{array}{c}-0.0645 \\
(5.00)\end{array}$ & n.d. & n.d. & $\begin{array}{c}-0.0772 \\
(8.08)\end{array}$ & n.d. \\
\hline
\end{tabular}

( ) actually measured $\mathrm{pH}$ values; n.d. $=$ not detected. 
the value for $\mathrm{m} / \mathrm{n}$ found was 2.2962 for $\mathrm{E}_{\mathrm{pa}}=-0.0645 \mathrm{~V}$ in $\mathrm{pH} 5.00$ and for $0.0493 \mathrm{~V}$ in $\mathrm{pH} 4.16$, confirming the data in the distribution diagram and the formation constants for this ligand and $\mathrm{M}$.

The metal to ligand ratio 1:3 for all studied ligands showed values of $\mathrm{m} / \mathrm{n}$ near 1 , making the systems very little likely to form the species $\mathrm{ML}_{3}$ confirming the results shown by potentiometric titration.

\section{Conclusion}

The alternative of using nitro humic substances (NHS), a laboratory artifact, as slow release fertilizers has the main objective of increasing the nitrogen content available to the plants. The nitrophthalic acids, the nitrohumic likely models studied in this work, although showing complexing ability with $\mathrm{Mo}^{6+}$ in $\mathrm{pH}$ values below 6.5 , not that suitable for soil chemistry, is randomly present in the structure of NHS along with catechol and salicylic binding sites. Other results to be released with salicylic NHA model derivatives and the results with 4-NC (refer to this work) showed that there are $\mathrm{Mo}^{6+}$ complexes until $\mathrm{pH}$ 8.0. There is, then, a compromise among those binding sites, rendering $\mathrm{Mo}^{6+}$ available after the mineralization of those substances.

The complexation of the HS to the molybdenum metal ion showed that HA through those results of the HA likely models are contributors to strong and weak ligand classes which control this metal ion speciation in both soil and water capable of receiving inputs of terrestrial organic matters and wastewaters. Also the stability constants can pave the way to further studies where the mathematical matrix must be filled with as much as the present complex species information ever possible, since the greater difficulty in studying humic acid systems where metal ions is present.

Also to report the metal loading of a system, the determination of the formation constants for the complexes is important, as in the matrix of the calculations to determine these constants the exact amount of the binding sites is also calculated using the data obtained in experiments such as those of models and potentiometric titrations. ${ }^{38,39}$

\section{References}

1. Schnitzer, M.; Khan, S.U.; Humic Substances in the Environment; Marcel Dekker: New York, 1972.

2. Perdue, E.M.; Geochim. Cosmochim. Acta 1978, 42 , 1351.

3. Bondietti, E.; Martin, J.P.; Haider, K.; Soil Sci. Soc. Am. Proc. 1972, 36, 597.

4. Haider, K.; Martin, J.P.; Filip, Z. In Humus Biochemistry. Soil Biochemistry, 4; Paul, E.D.; Mc Laren, A.D. eds., Marcel Dekker: New York, 1974, p.195-244.
5. Stevenson, F.J.; Humus Chemistry: Genesis Composition Reaction; John Wiley \& Sons: New York, 1982.

6. Coelho, R.R.R.; Linhares, L.F.; Martin, J.P.; Plant Soil 1985 , 87, 337.

7. Coelho, R.R.R.; Linhares, L.F.; Martin, J.P.; Plant Soil 1988, 106, 127.

8. Mangrich, A.S.; Vugman, N.V.; Sci. Total Environ. 1988, 1988, 235.

9. Mangrich, A.S.; Vugman, N.V.; Fuel 1990, 69, 925.

10. Griffith, S.M.; Schnitzer, M. In Humic Substances II in Search of Structure; Hayes, M.H.B.; MacCarthy, P.; Malcolm, R.L.; Swift, R.S., eds.; John Wiley \& Sons: UK, 1989, p.69-98 and references cited therein.

11. Schnitzer, M.; Soil Sci. 1991, 151, 41.

12. Schulten, H R.; Schnitzer, M.; Soil Sci. Soc. Am. J. 1991, 56, 1811.

13. Schulten, H R.; Schnitzer, M.; Naturwissenschaften 1995, 82, 487.

14. Cotton, F.A.; Wilkinson, G.; Advanced Inorganic Chemistry; Wiley Interscience: New York, 1972.

15. Howard, J.B.; Rees, D.D.; Annu. Rev. Biochem. 1994, 63, 235.

16. Fraústo da Silva, J.J.R.; Williams, R.J.P.; The Biological Chemistry of the Elements. The Inorganic Chemistry of Life; Clarendon Press: Oxford, 1997, p. 427.

17. Soni, R.; Bartusek M.; J. Inorg. Nucl. Chem. 1971, 33, 2557.

18. Prasad, S.; Guimarães, T.L.M.; J. Braz. Chem. Soc. 1998, 9, 253.

19. Cruywagen, J.J.; Heyns, J.B.B.; Rohwer, E.F.C.H.; J. Inorg. Nucl. Chem. 1978, 40, 53.

20. Cruywagen, J.J.; Heyns, J.B.B.; Rohwer, E.A.; J.Chem Soc. Dalton Trans. 1994, 1994, 45.

21. Cruywagen, J.J.; Rohwer, E.A.; van de Water, R.F.; Polyhedron 1997, 16, 243.

22. Vasconcelos, M.T.S.D,; Gomes, C.A.R.; Eur. Polym. J. 1997, 33,631 .

23. Takahashi, Y.; Minai, Y.; Ambe, S.; Makide, Y.; Ambe, F.; Tominaga, T.; Sci. Total Environ. 1997, 198, 61.

24. Kinniburgh, D.G.; van Riemsdijk, W.H.; Koopal, L.K.; Borkovec, M.; Benedetti, M.F.; Avena, M.J.; Colloids Surf. A 1999, 151, 147.

25. Lubal, P.; Siroký, D.; Fetsch, D.; Havel, J.; Talanta 1998, 47, 401.

26. Ceppi, S.B.; Velasco, M.I.; De Pauli, C.P.; Talanta 1999, 50, 1057.

27. Glaus, M.A.; Hummel, W.; Van Loon, L.R.; Appl. Geochem. 2000, 15, 953.

28. Kam, S K.; Gregory, J.; Wat. Res. 2001, 35, 3557.

29. Tipping, E.; Rey-Castro, C.; Bryan, S.E.; Hamilton - Taylor, J.; Geochim. Cosmochim. Acta 2002, 66, 3211.

30. Bryan, E.; Tipping, E.; Hamilton-Taylor, J.; Comp. Biochem. Physiol. Part C 2002, 133, 37. 
31. Hamilton-Taylor, J.; Postill, A.S.; Tipping, E.; Harper, M.P.; Geochim. Cosmochim. Acta 2002, 66, 403.

32. Martell, A.E.; Smith, R. M.; NIST Critical Stability Constants of Metal Complexes. v 6.0, NIST Database 46; Gaithersburg: MD, USA, 2001.

33. Sierra, M.M.S.; Arend, K.; Fernandes, A.N.; Giovanela, M.; Szpoganicz, B.; Anal. Chim. Acta 2001, 445, 89.

34. Szpoganicz, B.; Gidanian, S.; Kong, P.; Farmer, P.; J. Inorg. Biochem. 2002, 89, 45.

35. Martell, A.E.; Motekaitis, R.J.; The Determination and Use of Stability Constants; VCH: New York, 1992.
36. Mercê, A.L.R.; Szpoganicz, B.; Dutra, R.C.; Khan, M.A.; Than, X.D.; Bouet, G.; J. Inorg. Biochem. 1998, 71, 87.

37. Mercê, A.L.R.; Lombardi, S.C.; Mangrich, A.S.; Reicher, F.; Szpoganicz, B.; Sierakowski, M.R.; Carbohydr. Polymer 1998, $35,13$.

38. Filella, M.; Town, R.M.; Fresenius J. Anal. Chem. 2001, 370, 413.

39. Burba, P.; Van den Bergh, J.; Klockow, D.; Fresenius J. Anal. Chem. 2001, 371, 660.

Received: April 3, 2004 Published on the web: November 18, 2004 